\title{
Baikal Issues under Persistent State Care Introduction
}

\author{
VERA KUKLINA
}

This special forum comprises articles based on papers presented at the session "Baikal Issues under Persistent State Care" at the 2012 Annual Meeting of the Association of American Geographers and serves as an introduction to the economic, social, and political dimensions of a unique natural object.

Baikal is the biggest reservoir of pure water and the only natural object in Russia protected by a special federal law- "On Protection of Lake Baikal" (1999). Baikal serves as a core for economic, social, and political processes across its watershed and beyond. Protests against the construction of the Baikal'sk Pulp and Paper Mill gave birth to the first environmental movement in the Soviet Union. Baikal gave name to the region that unites three entities of the Russian FederationIrkutsk oblast, Republic of Buriatiia, and Zabaikalskii krai), and to the Baikal-Amur Mainline that runs north of and parallel to the TransSiberian Railway. More recently, the "Baikal" brand was used for the Baikal economic forum that serves as a platform for discussions about trans-boundary and inter-regional cooperation and collaboration between members of the Business Council of the Shanghai Cooperation Organization and Association of South East Asian Nations.

Baikal has been on the UNESCO World Heritage list since 1996; at the 2012 World Heritage Committee meeting in Saint Petersburg, some participants proposed to include it in the List of World Heritage in Danger. Degradation of water quality in Baikal as well as degradation of the Siberian taiga are problems whose consequences will not affect only Russia but the global environmental system in general.

The vast area of the Baikal region can be considered as a model for all the Siberian regions because it embraces northern regions with Arctic conditions, mountainous areas, and Central Asian borderlands. Reopening Baikal Pulp and Paper Mill, creation of Special economic zones on the shores of Lake Baikal, new plans to make investments into specially protected areas, and projects for mine extractions and 
constructions of infrastructure in the north embrace almost all of the issues important for Siberia. The difficulties of considering the Baikal region as a whole are due to its ethnic, cultural, and geographical diversity. The region easily breaks up into east and west, but even more evident is the north-south division. The latter is more perceived by inhabitants of the north than by those in the south, as is typical in colonial regimes where the center does not see the difference of people on its margins. The findings of various aspects of the Baikal regionphysical-geographical characteristics of specially protected areas, social and economic situations in the region, ethno-cultural barriers of its residents-are presented in the following research reports by geographers of the V. B. Sochava Institute of Geography of the Siberian Branch of the Russian Academy of Sciences in Irkutsk.

The Institute of Geography was established in 1957 for the study of natural resources in Siberia and the potential for their exploration. Since then, the main focus has shifted to studies of natural geosystems and their components and the practical implementation of geographic methods and tools. The institute's researchers participate in territorial planning on regional and local levels, provide environmental impact assessment of industrial projects, prognosis and analysis of demographical trends in the region, and Geographic Information Systems support of different kinds of territorial analysis. Its members have participated in implementation of the Federal Law "On protection of Lake Baikal," substantiating zones of atmospheric, water, and land impact with specification of limitations of economic activity in each zone within the Baikal natural territory. These zones were approved by the government of the Russian Federation. Unfortunately, special regulating mechanisms were not implemented.

Gerelma Dugarova and Victor Bogdanov discuss the impact of environmental restrictions on social and economic development on the territories around Lake Baikal. They show that the economic costs of preserving Baikal's natural resources at the regional and local levels are much higher than any other activity under current economic conditions. However, there is hope that environment-friendly economic activities can be profitable if the state were to provide support.

There is a complicated overlapping of economic and environmental interests in the Baikal's officially protected areas. Natalia Luzhkova discusses management and policy in the Baikal Nature Reserve (Baikal'skii zapovednik) - a protected area with the strictest regime. Irina Bilichenko summarizes an environmental impact analysis for the Tunkinskiy National Park, considering local inhabitants' and tourists' dif- 
fering economic activities. Both authors focus on the activities of official organizations in these areas.

Vera Kuklina's article focuses on urban strategies for sustentation of ethnicity of Buriats in Irkutsk. Although it is not connected to Baikal issues directly, mutual understanding and collaboration between the Republic of Buriatiia and Irkutsk oblast are the essential condition for sustainable development of the Baikal region.

\begin{abstract}
Vera Kuklina is post-doctoral scholar of Geographical Sciences, research officer at the Department of Political Geography and Natural Resource Management of V.B. Sochava Institute of Geography at the Siberian Branch of the Russian Academy of Sciences, and researcher at the Centre for Independent Social Research and Education. She is the author of numerous publications. Her monograph Local Communities in the Multiethnic Environment of South Siberia: Cultural-Geographical View was awarded the V.B. Sochava Award for Young Scientists of the Siberian Branch of the Russian Academy of Sciences.
\end{abstract}

\title{
Acknowledgments
}

I thank the Trust for Mutual Understanding Foundation and the Association of American Geographers, and especially the Russian, Central Eurasian, and East European Specialty group for the support in organizing the session "Baikal Issues under Persistent State Care" at the 2012 Annual Meeting of the Association of American Geographers. A special thanks goes to the discussant of our session Timothy Heleniak for his careful reading and valuable comments on the papers at this session. 